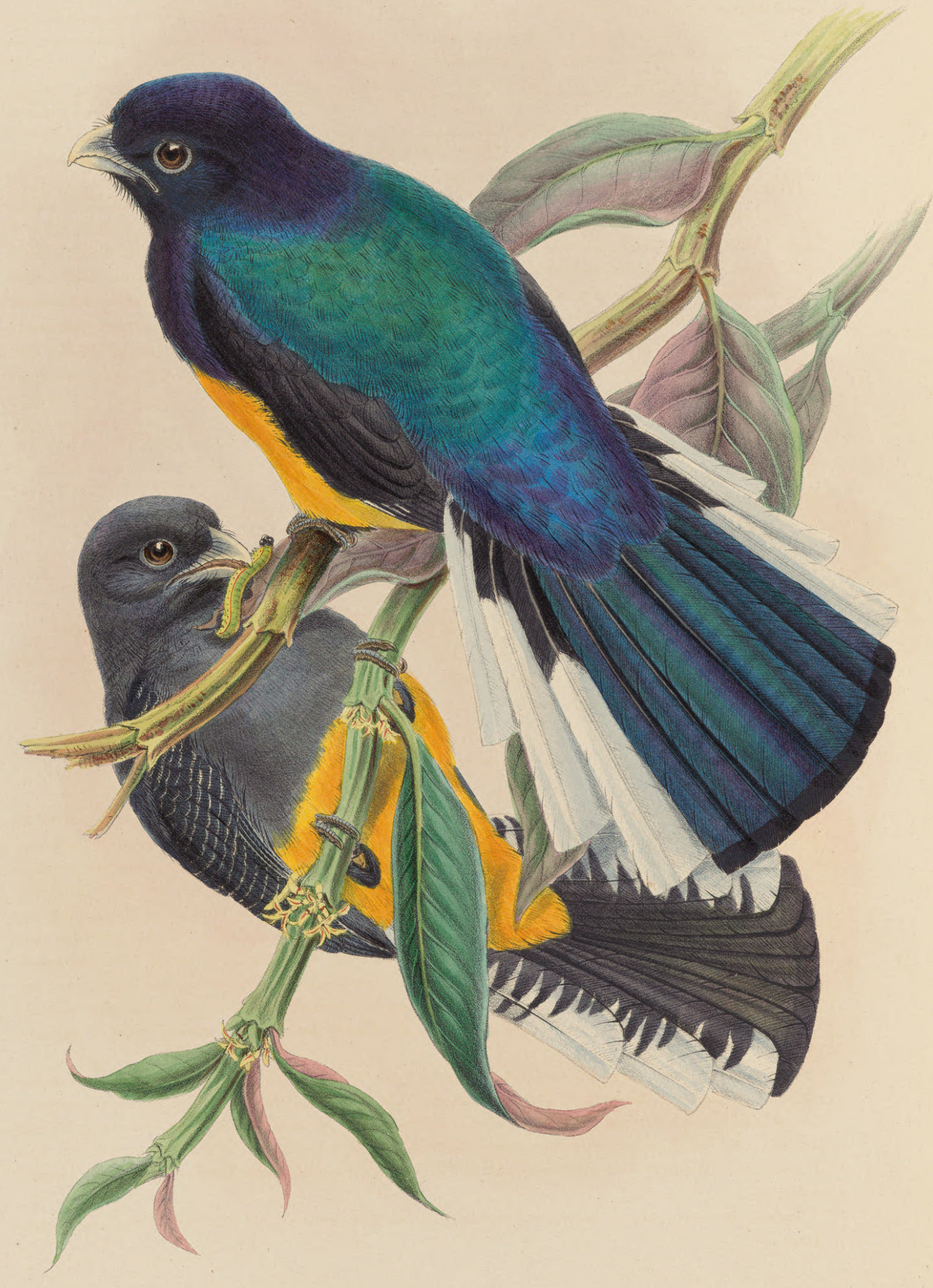




\title{
TROGON CHIONURUS.
}

\author{
The Snow-tailed Trogon.
}

\author{
Specific Character.
}

Trog. similis T. viridi, sed rectricibus externis fere omnino albis, ita ut cauda clausa omnino alba esse videtur.

Foem. Etiam rectricum externarum apices latè albos ostendit (Scl. \& Salv. l.c.).

Adult male.-Head and neck black, with a very slight gloss of purple; back purplish blue, glossed here and there with coppery green, shading off into rich dark purple on the rump and upper tail-coverts; wings entirely black, with the exception of the least coverts, which are coloured like the back; tail dull purple, tipped with black, and inclining to black on the inner web of all but the two centre feathers, the three outer tail-feathers white, with black bases, the latter increasing in extent gradually towards the centre of the tail; sides of face, throat, and upper breast black, the sides of the latter showing a purplish gloss, rest of under surface rich orange-yellow, the leg-feathers black; under wing-coverts black, the innermost whitish, the lower series ashy black, like the inner lining of the quills, the latter being ashy black with white bases to the inner webs of the median primaries.

Total length $10_{\frac{1}{2}}^{1}$ inches; culmen $\frac{3}{4}$; wing $5 \frac{1}{4}$; tail 6 ; tarsus $\frac{1}{2}$.

Female.-Greyish above and on the lower parts, including the breast; the rest of the under surface rich orange; wings black, the coverts narrowly barred with white; the outer tail-feathers tipped with white and barred with black on the rest of the white of these feathers.

Trogon viridis, Scl. \& Salv. P. Z. S. 1864, p. 364.-Lawr. Ann. Lyc. N. Y. vii. p. 290. chionurus, Scl. \& Salv. P. Z. S. 1870, p. 843.-Wyatt, Ibis, 1871, p. 374.—Scl. \& Salv. Nomencl. Av. Neotr. p. 304.

eximius, Lawr. Ann. Lyc. N. Y. x. p. 11.

I наVе taken the characters of this species from Messrs. Sclater and Salvin; and I think I cannot do better than reproduce their remarks on the affinities of the species:- "We have examined numerous specimens of this Trogon from Panama, and have hitherto referred it to T. viridis. We convinced ourselves some time ago, on examining an example from Mr. Lawrence's collection, that is was not really $T$. viridis, but were then doubtful whether it might not be T. venustus, Cab. \& Hein. (Mus. Hein. iv. p. 194). On going into the question again, aided by additional skins of $\boldsymbol{T}$. viridis from various localities, we feel convinced that T. vemustus (as characterized l.s. c.) cannot be considered really distinct from T. viridis. We have specimens of this bird now before us from Rio, Bahia, Matto Grosso, Eastern Venezuela, and Bogota, and can find no constant differences amongst them, although there is considerable diversity of tint in the colour of the lower back, and some specimens approach to what Dr. Finsch has recently proposed to call $\boldsymbol{T}$. cyanurus (P. Z. S. 1870, p. 559)!

"On the other hand, three Panama skins in the collection of Salvin and Godman present the remarkable character of the outer tail-feathers above mentioned. The first outer pair are all pure white except a narrow basal patch concealed by the tail-coverts. Of the second pair considerably more than the apical half is white. In the third pair the white apices measure 2 inches in length. We therefore call this bird T. chionurus. We have seen other examples of this Panama species in Mr. Lawrence's and Mr. Gould's collections."

Nothing is known of the habits and economy of this fine species; but Mr. Salvin, in a note to me, states :- 
“This beautiful species may readily be distinguished from the well-known $T$. viridis by the much greater development of white in the tail-feathers. The first outer pair are all pure white, except a narrow basal patch concealed by the tail-coverts. Of the second pair considerably more than the apical half is white; in the third pair the white apices measure 2 inches in length. When the tail is closed the under surface appears perfectly white. Comparing the amount of white in the tail with that shown in $T$. viridis the distinctness of the two birds is apparent.

"Notwithstanding this difference, the species remained for several years undescribed both in $\mathrm{Mr}$. Lawrence's cabinet and our own; but in $1870 \mathrm{Mr}$. Sclater and I had occasion to reexamine the question, when it became manifest that this fine species required a name. About the same time Mr. Lawrence also bestowed the name eximius upon it.

"The first specimens of this species were forwarded to Mr. Lawrence from the Panamá-Railway line, by the late Mr. James M'Leannan, who afterwards supplied Mr. Godman's and my collection with skins of both sexes. The bird does not seem to extend its range into Central America beyond the railway (though it is there not uncommon), as our collector Arcé did not meet with it in the district of Veragua, which he has so carefully investigated. Further to the southward we know very little of its range, as it does not come within the grasp of the bird-collectors of Bogotá. Mr. Wyatt, however, when travelling in the valley of the river Magdalena, shot a female Trogon which Mr. Sclater and I determined to be of this species. He met with it in the forest near Paturia, and says that he heard the male calling further in, and he noted that the iris was dark brown (Ibis, 1871, p. 374). From this it would appear that the home of Trogon chionurus is the low-lying hot forests of the great valley of the Magdalena, and that it extends its range into the CentralAmerican isthmus as far as the foot of the mountains which form the higher ranges of Veragua and Costa Rica."

The Plate represents a male and a female, of the natural size. 


\section{$2 \mathrm{BHL}$ Biodiversity Heritage Library}

Gould, John. 1875. "The Snow-tailed Trogon, Trogon chionurus." A monograph of the Trogonidce or trogons 3, -. https://doi.org/10.5962/p.323641.

View This Item Online: https://www.biodiversitylibrary.org/item/264866

DOI: https://doi.org/10.5962/p.323641

Permalink: https://www.biodiversitylibrary.org/partpdf/323641

\section{Holding Institution}

Harvard University, Museum of Comparative Zoology, Ernst Mayr Library

\section{Sponsored by}

Harvard University, Museum of Comparative Zoology, Ernst Mayr Library

\section{Copyright \& Reuse}

Copyright Status: Public domain. The BHL considers that this work is no longer under copyright protection.

This document was created from content at the Biodiversity Heritage Library, the world's largest open access digital library for biodiversity literature and archives. Visit BHL at https://www.biodiversitylibrary.org. 